\title{
APLIKASI WEB SCRAPING DESKRIPSI PRODUK
}

\author{
Dana Febri Setiawan'), Tristiyanto ${ }^{2)}$, Astria Hijriani ${ }^{3)}$ \\ ${ }^{1,2,3}$ Ilmu Komputer, Universitas Lampung \\ 1,2,3 A Jalan Soemantri Brojonegoro No.1 Gedung Meneng, Bandar Lampung \\ Email: 'dana.febrisetiawan1527@students.unila.ac.id, ${ }^{2}$ tristiyanto.1981@fmipa.unila.ac.id, \\ 3astria.hijriani@fmipa.unila.ac.id
}

\begin{abstract}
Abstrak
Situs-situs e-commerce dan e-marketplace di Indonesia menawarkan setiap produk dengan deskripsi dan harga yang berbeda-beda. Oleh karena itu pengisian deskripsi dengan jumlah kata yang sangat banyak dan beragam, maka dapat menghabiskan waktu yang sangat lama dalam mengelola produk. Keterbatasan dalam mengelola deskripsi produk secara detail ini dapat diatasi dengan proses pengambilan informasi dengan web scraping. Web scraping adalah proses pengambilan sebuah dokumen semi-terstruktur dari internet, umumnya berupa halamanhalaman web dalam bahasa markup seperti HTML atau XHTML, dan menganalisis dokumen tersebut untuk diambil data tertentu dari halaman tersebut untuk digunakan bagi kepentingan lain. Pembangunan website ini dilakukan dengan menggunakan framework Laravel dan dengan metode pengembangan sistem waterfall. Hasil implementasi dari sistem informasi web scraping ini adalah teknik web scraping dapat digunakan untuk mengambil konten deskripsi produk dengan cepat dan tepat di berbagai situs e-commerce dan e-marketplace seperti Tokopedia, Bukalapak, Lazada, Zalora, Blanja.com, Kriya.co.id, Zilingo, Amazon, dan Alibaba yang memuat deskripsi penjualanan produk. Penyimpanan deskripsi produk ke dalam database, mempermudah transformasi data ke bentuk lainnya.
\end{abstract}

Kata Kunci: aplikasi, web, web scraping, e-commerce, emarketplace

\section{PENDAHULUAN}

Selama ini pelaku penjualan online memiliki kontribusi yang tidak sedikit terhadap pertumbuhan perekonomian Indonesia [1]. Di Indonesia penjualan online masih mengandalkan media interaksi dengan konsumen (pelanggan) secara langsung dan masih berpusat pada lokasi tertentu sehingga pemasaran secara online sangat penting seperti melalui e-commerce dan e-marketplace [2].

Situs-situs e-commerce dan e-marketplace di Indonesia menawarkan setiap produk dengan deskripsi dan harga yang berbeda-beda. Deskripsi dengan jumlah kata yang sangat banyak dan beragam sehingga dapat menghabiskan waktu yang sangat lama dalam mengelola produk [3]. Keterbatasan dalam mengelola deskripsi produk secara detail ini dapat diatasi dengan proses pengambilan informasi dengan Web scraping [4].

Web scraping adalah proses pengambilan sebuah dokumen semi-terstruktur dari internet, umumnya berupa halaman-halaman Web dalam bahasa markup seperti HTML (HyperText Markup Language) atau XHTML (Extensible HyperText Markup Language), dan menganalisis dokumen tersebut untuk diambil data tertentu dari halaman tersebut untuk digunakan bagi kepentingan lain. Bahasa markup adalah bahasa komputer yang menggunakan tag untuk mendefinisikan elemen dalam dokumen [5].

Web scraping sering dikenal sebagai screen scraping. Web scraping tidak dapat dimasukkan dalam bidang data mining karena data mining menyiratkan upaya untuk memahami pola semantik atau tren dari sejumlah besar data yang telah diperoleh [6].

Beberapa penelitian terdahulu yang merancang dan membangun sistem informasi Web scraping yaitu dengan merancang bangun aplikasi Web scraping untuk korpus paralel Indonesia-Inggris dengan metode HTML DOM (Document Object Model) [7]. Pada penelitian di Univerisitas Gunadarma Anlisis Web Scraping untuk data bencana alam dengan menggunakan teknik breadth-first search terhadap 3 media online [8].

Dalam penelitian ini, penulis mengembangkan sistem informasi Web scraping untuk pengisian deskripsi produk penjualan online pada marketplace. Penulis dapat mengambil data produk, gambar produk, deskripsi produk, harga produk dan juga URL (Uniform Resource Locator) produk pada e-marketplace seperti Tokopedia, Bukalapak, Lazada, Zalora, Blanja.com, Kriya, Zilingo, Amazon, dan Alibaba dengan teknik Web scraping untuk pengisian produk penjualan online pada e-marketplace yang telah di buat. Pembangunan sistem informasi Web scraping menggunakan framework Laravel dan database $M y S Q L$ sebagai penyimpanan datanya.

\section{METODE PENGEMBANGAN SISTEM}

Sistem Informasi ini dikembangkan menggunakan metode Waterfall dan digunakan untuk membantu mengatasi masalah pengisan produk dengan jumlah yang sangat banyak. Tahapan yang dilakukan pada metode Waterfall ditunjukkan pada Gambar 1. 


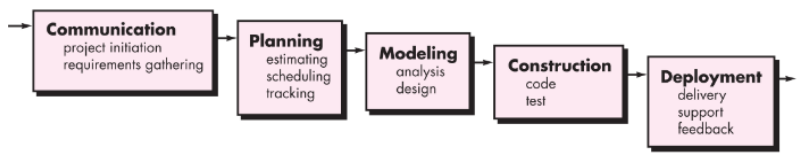

Gambar 1. Metode Waterfall [9].

\section{A. Communication}

Pada tahapan ini dilakukan komunikasi dengan pengguna untuk mengetahui bagaimana cara kerja pada sistem informasi Web scraping itu sendiri. Hasil dari tahapan ini yaitu:

a) Mengelola dan melihat data e-marketplace seperti Tokopedia, Bukalapak, Lazada, Zalora, Blanja.com, Kriya.co.id, Zilingo, Amazon, dan Alibaba

b) Melakukan registrasi pengguna

c) Merubah profil pengguna

d) Menambahkan data produk.

e) Mengelola data daftar scraping.

f) Merubah setting scraping e-marketplace.

Hasil dari wawancara didapatkan modul-modul yang diinginkan pengguna terhadap sistem yang digambarkan pada use case diagram Gambar 2.

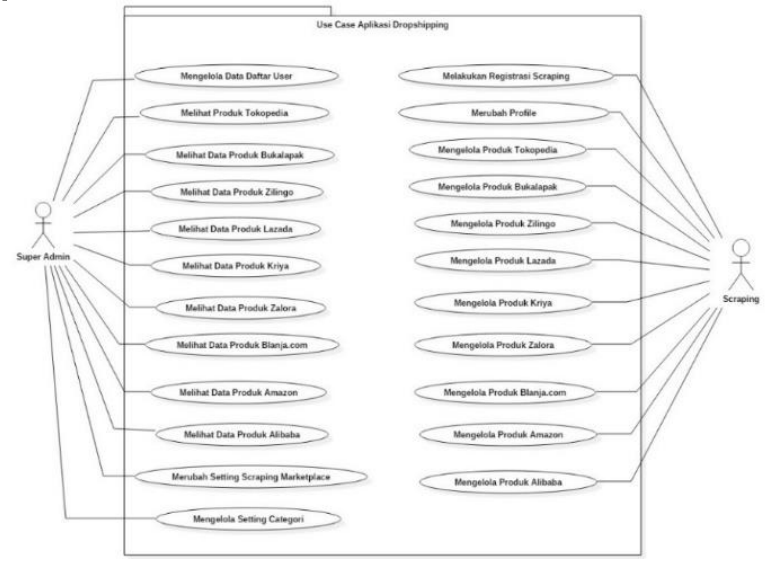

Gambar 2. Use Case Diagram.

Pada Gambar 2 dapat dilihat bahwa ada dua level user yang berbeda. User tersebut dapat melakukan seperti berikut.

\section{a) Super Admin}

Super Admin adalah pengembang dari sistem informasi scraping. Super admin dapat melihat dan menghapus seluruh data produk Tokopedia, Bukalapak, Lazada, Zalora, Blanja.com, Kriya.co.id, Zilingo, Amazon, dan Alibaba. Mengelolah data daftar scraping dan merubah setting scraping marketplace. Super admin hanya dapat mensuspend dan menghapus akun di data daftar user. Super admin dapat mengengelola setting kategori.

\section{b) Scraping}

Scraping adalah mengelola dari salah satu admin dan pengguna yang menggunakan sistem informasi Web scraping. Scraping harus melakukan registrasi dan merubah profil. Scraping dapat mengelola dan menampilkan data produk Tokopedia, Bukalapak, Lazada, Zalora, Blanja.com, Kriya.co.id, Zilingo, Amazon, dan Alibaba. Penguna data produk dapat melihat url yang sudah discraping dari Tokopedia, Bukalapak, Lazada, Zalora, Blanja.com, Kriya.co.id, Zilingo, Amazon, dan Alibaba.

\section{B. Planning}

Tahap perencanaan sistem ini terlebih dahulu harus merencanakan tentang project apa yang akan dibuat atau dengan kata lain harus mendifinisikan masalah yang harus dipecahkan. Bagaimana cara membuat sistem informasi Web scraping untuk pengisian deskripsi produk pada emarketpalce sehingga diharapkan nantinya dapat memudahkan pengguna untuk mengisi data produk, dengan jumlah produk yang sangat banyak.

\section{Modelling}

Tahap ini akan dilakukan desain pada sistem, tahap ini dilakukan sebelum melakukan pengkodean. Tahap ini bertujuan untuk memberikan gambaran apa yang harus dikerjakan dan bagaimana tampilannya. Tahapan ini dilakukan dengan melakukan desain use case diagram, activity diagram, class diagram, Sequence diagram, dan desain interface sistem.

\section{Construction}

Tahap ini dilakukan teknik automasi dengan parsing HTML untuk melakukan Web scraping. Tahap untuk melakukan scraping adalah request URL yang di jadikan target, request diproses oleh server target, hasil dari request dari URL hasilnya adalah teks dengan format HTML, lalu ekstrak data, kemudia hasil dari ekstrak akan menentukan output yang diinginkan. Selain itu juga construction merupakan tahap dalam penulisan kode program menggunakan bahasa pemrograman PHP dan framework Laravel. Dilakukan pengujian terhadap sistem, pengujian dilakukan mengenai fungsionalitas program dengan black box testing.

\section{E. Deployment}

Setelah tahapan construction selesai maka tahap selanjutnya adalah sistem akan dipergunakan pada pengguna dan dilakukan pemeliharaan sistem.

\section{HASIL DAN PEMBAHASAN}

\section{A. Tahapan Scraping}

Tahapan scraping ini memiliki 5 tahapan, masing-masing tahapan memiliki fungsi fase yang sesuai pada kriterianya. Bila fungsi fase sedang di proses, maka fase selanjutnya akan menunggu sampai fungsi selanjutnya di panggil.

\section{1) Parsing $H T M L$}

Parsing HTML adalah salah satu teknik yang paling banyak digunakan dalam web parsing. Biasanya parsing 
HTML dilakukan melalui JavaScript dan menarget halaman HTML linear dan nested. Metode yang cepat ini mengidentifikasi script HTML dari website, yang mungkin saja dilakukan secara manual sebelumnya. Script ini kemudian digunakan untuk mengekstraksi text, links, dan data. Parsing data pada aplikasi web scraping ini menggunakan file HTML milik Bukalapak. Gambar 3 menunjukkan contoh kode program menggunakan bahasa pemrograman PHP dalam proses parsing data HTML menjadi data objek.

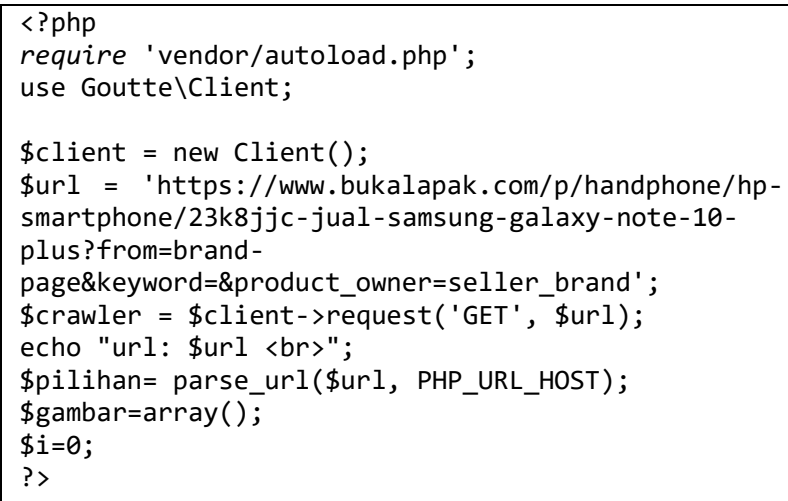

Gambar 3. Kode Program Parsing HTML Bukalapak.

File HTML tersebut berisi informasi data produk yang bisa di proses menjadi informasi. Selanjutnya file HTML tersebut di parsing kedalam sebuah data Objek yang diproses menuju tahap selanjutnya. Berikut contoh output dari data hasil parsing file HTML pada Gambar 4.

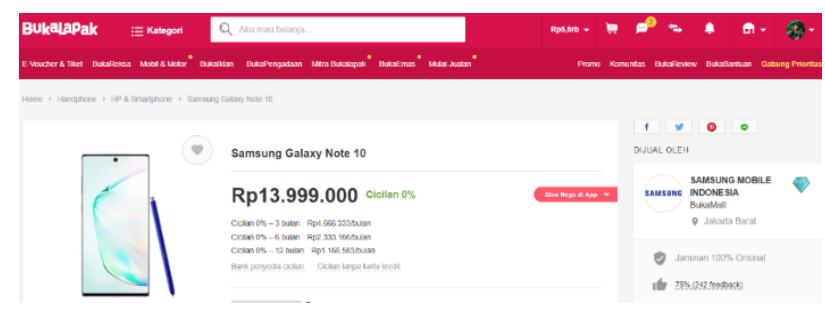

Gambar 4. Hasil Parsing HTML Bukalapak.

\section{2) Parsing DOM}

Parsing DOM merupakan Konten,style, dan struktur file XML didefinisikan dalam DOM, kependekan dari Document Object Model. Scrapers yang ingin mengetahui cara kerja internal halaman web dan mengekstrak skrip yang berjalan di dalamnya biasa memilih untuk melakukan web scraping melalui parsing DOM. Node spesifik dikumpulkan menggunakan parser DOM dan alat-alat seperti XPath membantu proses scraping sebuah halaman web. Berikut kode program dari parsing DOM dan Xpath pada gambar 5.

\$DOM = new DOMDocument;
libxml_use_internal_errors(true);
if (! \$DOM->loadHTML(\$page) $)$
$\{\quad$ \$errors $="$ ";

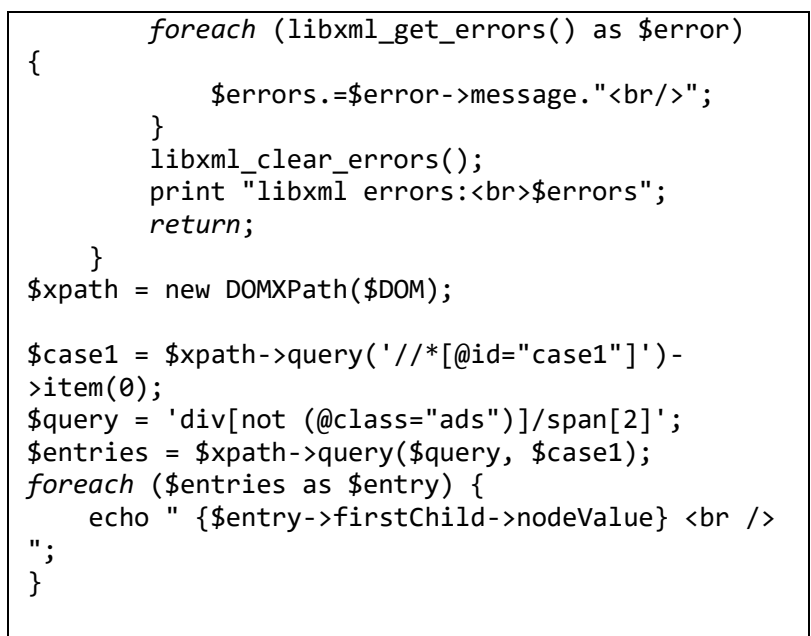

Gambar 5. Kode Program HTML DOM dan Xpath.

\section{3) Triming}

Triming adalah suatu cara memotong atau penghilangan suatu data yang tidak dikehendaki. Trimming berfungsi mengelola suatu string request dari class tag bukalapak yang menjadi sebuah kata kunci yang dapat diproses. Dalam tahap trimming ini dilakukan di inspect element yang ada pada browser untuk melakukan scraping data berdasarkan class yang sudah ada. Pada gambar 6 ditujukkan inspect element pada kasus nama_produk "Samsung Galaxy Note 10".

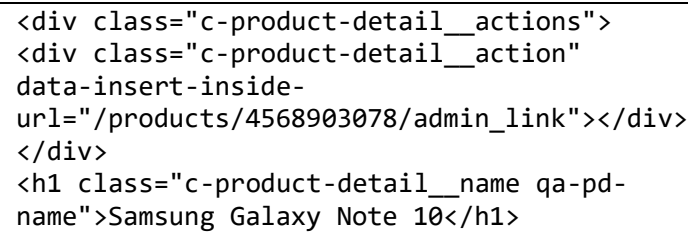

\section{Gambar 6. Proses Triming.}

Dilakukan triming pada class "c-product detail name qa-pd-name" yang akan di salin pada kode program pada tahap saving.

\section{4) Saving}

Tahap saving merupakan tahapan dimana hasil trimming disimpan dalam sebuah variable \$pilihan. Seperti Gambar 7 hasil trimming nama produk akan disimpan ke variable \$pilihan berikut juga data-data yang berhubungan dengan request class tag pada bukalapak yang akan discraping.

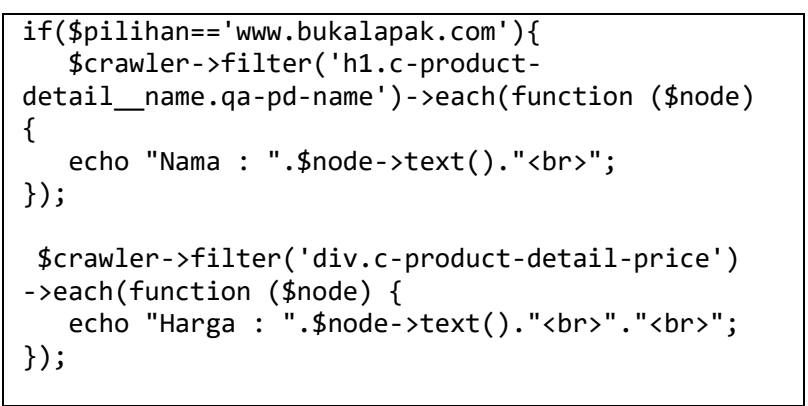




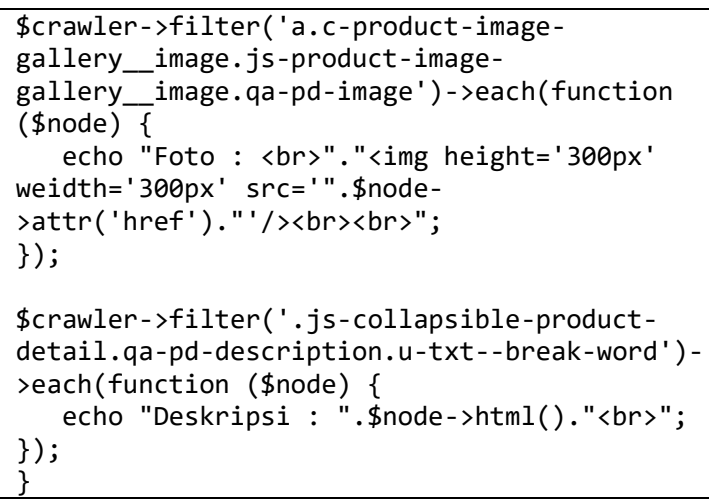

Gambar 7. Kode Program Menyimpan data triming di sebuah variable.

\section{5) Compile}

Pada tahap ini adalah data harus diolah menjadi sebuah informasi untuk dapat memahami data produk yang ada pada Bukalapak yang ada. Data produk yang ada pada Bukalapak seperti nama_produk, harga, foto dan deskripsi. Gambar 8 akan menampilkan hasil dari web scraping yang berhasil di scraping pada e-marketplace Bukalapak.

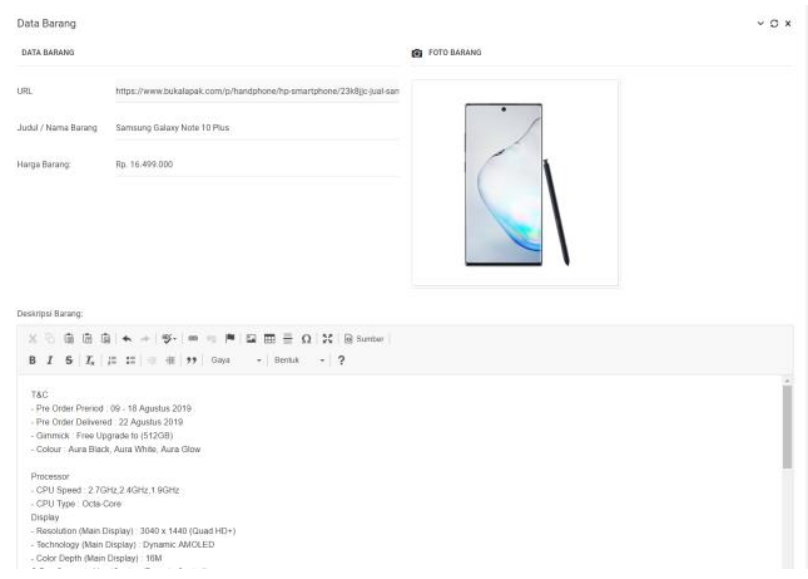

Gambar 8. Hasil Scraping Produk.

\section{B. Implementasi Sistem}

Implementasi sistem dilakukan setelah tahap analisis dan perancangan selesai dilakukan. Implementasi sistem dilakukan pengkodean sistem menggunakan bahasa PHP dan framework Laravel. Hasil implementasi sistem pada SI Web scraping ditunjukkan dengan tampilan halaman profil, halaman tambah produk, halaman data produk, halaman setting scraping e-marketplace, dan halaman setting kategori.

\section{1) Halaman Profil}

Gambar 9 menunjukkan tampilan Halaman Profil Scraping merupakan halaman yang menyajikan data pribadi dari user scraping yang sedang login. Pada halaman profil, pengguna dapat merubah data pribadi serta foto profil dan dapat merubah email dan password.

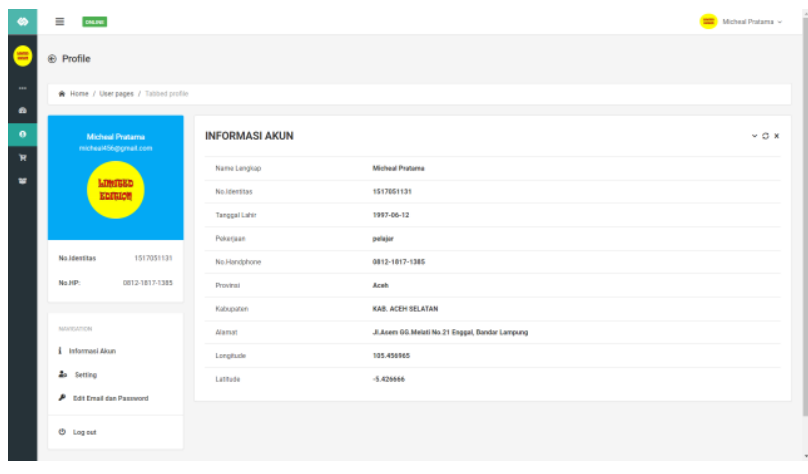

Gambar 9. Halaman Profil.

2) Halaman Tambah Produk

Gambar 10 menunjukkan tampilan Halaman tambah produk merupakan halaman untuk menambahkan produk dari e-marketplace yang ditentukan hanya dengan mencari url e-marketplace lalu mencarinya, maka akan otomatis mendapatkan nama produk, harga, deskripsi dan foto produk.

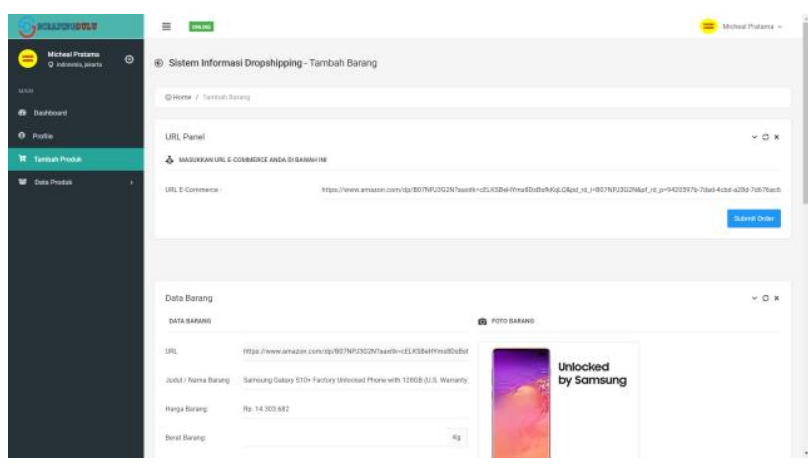

Gambar 9. Halaman Tambah Produk.

3) Halaman Data Produk

Gambar 10 menunjukkan menunjukkan tampilan halaman data produk merupakan halaman yang menyajikan data produk yang terdapat tabel review, nama barang, harga, stock, stasus barang dan actions. Pada tabel actions terdapat menu GO TO URL (Uniform Resource Locator), lihat, edit, dan hapus.
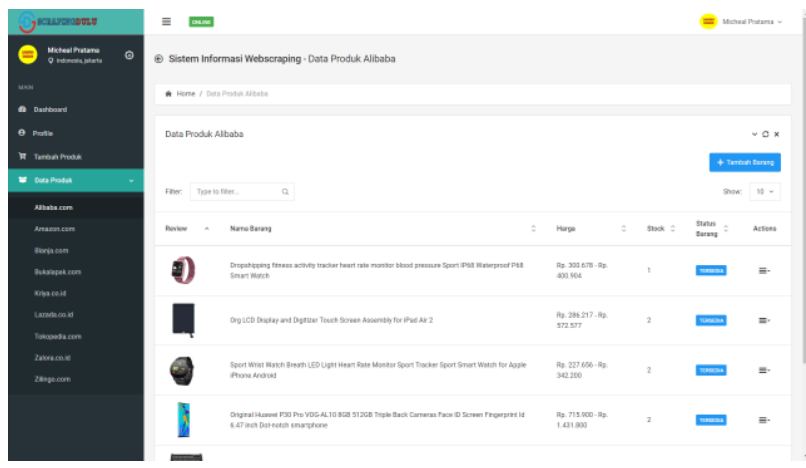

Gambar 10. Halaman Data Produk.

4) Halaman Setting Scraping E-Marketplace Gambar 11 menunjukkan tampilan Halaman setting 
scraping e-Marketplace pada super admin merupakan halaman untuk merubah pengaturan scraping pada tiaptiap e-marketplace.
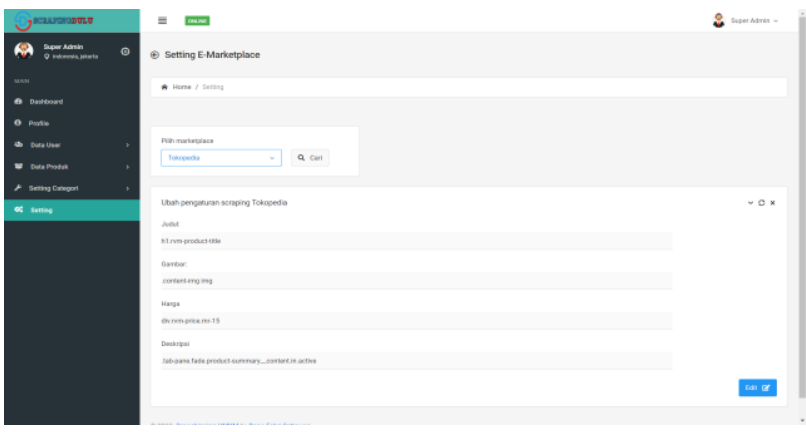

Gambar 11. Halaman Setting Scrpaing E-Marketplace.

\section{5) Halaman Setting Kategori}

Gambar 12 menunjukkan tampilan Halaman Setting Kategori Pada Super Admin merupakan tampilan yang menyajikam data pada kategori yang terdapat actions. Pada tabel actions terdapat menu tambah, edit, dan hapus.

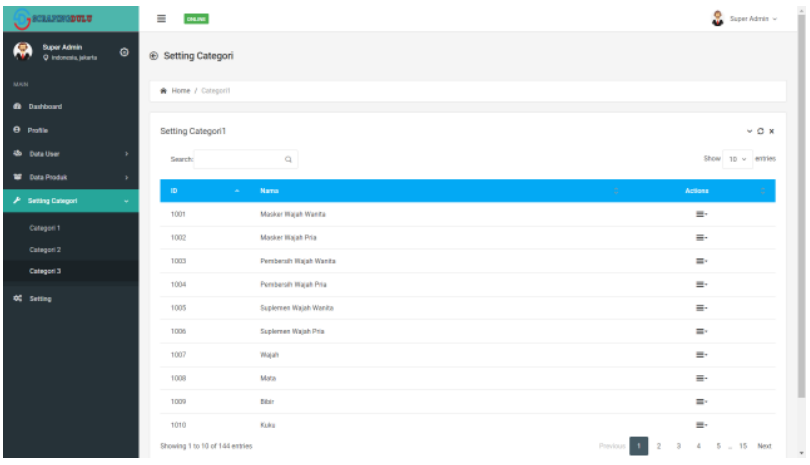

Gambar 12. Halaman Setting Kategori.

\section{Pengujian Sistem}

Tahap ini menggunakan pengujian black box dengan metode EP (Equivalence Partitioning). EP akan membagi domain masukan dari program ke kelas-kelas sehingga test case dapat diperoleh. Dari keluaran yang dihasilkan, kemampuan program dapat memenuhi kebutuhannya dapat diketahui beberapa kesalahan, yaitu kesalahan struktur data dan kesalahan fungsi tidak benar atau hilang. Berdasarkan hasil pengujian yang telah dilakukan, hasil diharapkan sudah sesuai dengan hasil yang sebenarnya. Dengan demikian sistem yang dibangun sudah dapat berfungsi dengan kebutuhan pengguna.

\section{Hasil}

Hasil yang di dapat pada SI Web Scraping adalah sistem yang di bangun guna mempermudah penjual online untuk melakukan pengisian data produk seperti nama produk, harga, deskripsi, dan gambar dari produk yang telah discraping. Web scraping tersebut dapat melakukan scraping data pada 9 e-marketplace yaitu Alibaba, Amazon, Blanja.com, Bukalapak, Kriya, Lazada,
Tokopedia, Zalora, dan Zilingo. SI Web scraping memiliki dua tingkatan user yaitu Super admin dan user scraping. Super Admin bertugas sebagai pengelola SI Web scraping, dimana super admin dapat melihat jumlah scraping produk pada masing-masing e-marketplace dan dapat melihat total scraping yang terdaftar.

Super admin memiliki akses untuk melihat profil user scraping dan melakukan suspend atau restore akun user scraping. Super admin dapat melihat dan menghapus produk pada setiap e-marketplace seperti Tokopedia, Bukalapak, Lazada, Blanja, Kriya, Zalora, Zilingo, Alibaba, Amazon. Super admin dapat menambahkan data kategori 1, kategori 2 dan kategori 3. Kemudian super admin juga dapat merupah setting scraping pada setiap masing-masing e-marketplace. User scraping dapat mendaftar sebagai admin dan harus melakukan verifikasi melalui email untuk dapat masuk ke SI Web scraping. User scraping dapat mengelola data produk Tokopedia, Bukalapak, Lazada, Blanja, Zilingo, Zalora, Kriya, Amazon, Alibaba. User scraping dapat merubah informasi yang sebelumnya didaftarkan dan dapat merubah email dan password.

Table 1. Hasil Pengujian Keberhasilan Scraping Pada EMarketlace

\begin{tabular}{clllll}
\hline No & Markeplace & Produk & Produk & $\begin{array}{l}\text { Deskripsi } \\
\text { Produk }\end{array}$ & $\begin{array}{l}\text { Foto } \\
\text { Produk }\end{array}$ \\
\hline 1 & Tokopedia & Berhasil & Berhasil & Berhasil & Berhasil \\
2 & Bukalapak & Berhasil & Berhasil & Berhasil & Berhasil \\
3 & Blanja & Berhasil & Berhasil & Berhasil & Berhasil \\
4 & Zalora & Berhasil & Berhasil & Berhasil & Berhasil \\
5 & Zilingo & Berhasil & Berhasil & Berhasil & Berhasil \\
6 & Kriya & Berhasil & Berhasil & Berhasil & Berhasil \\
7 & Alibaba & Berhasil & Berhasil & Berhasil & Berhasil \\
8 & Amazon & Berhasil & Berhasil & Berhasil & Berhasil \\
9 & Lazada & Berhasil & Berhasil & Berhasil & Berhasil \\
& & Tidak & Tidak & \\
10 & Jd.id & Berhasil & berhasil & berhasil & Berhasil \\
& & Tidak & Tidak & Tidak & Tidak \\
11 & Shopee & berhasil & berhasil & berhasil & berhasil \\
& & Tidak & Tidak & Tidak & Tidak \\
12 & Blibli & berhasil & berhasil & berhasil & berhasil \\
\hline
\end{tabular}

Berdasarkan hasil pengujian keberhasilan pada table 1 bahwa dalam melakukan scraping data produk pada 12 marketplace bahwa ada yang berhasil dan tidak berhasil. Scraping data produk yang berhasil diantaranya yaitu Tokopedia, Bukalapak, Blanja, Zalora, Zilingo, Kriya, Alibaba, Amazon, dan Lazada. Pada marketplace Alibaba karena pada saat melakukan scraping deskripsi produk untuk gambar yang ada pada deskripsi itu tidak dapat scraping gambar yang ada pada deskripsi produk karena permasalahan yaitu ada pada placeholder gambar Alibaba yang menjadi gambar utamanya sehingga gambar produknya tidak dapat diproses karena berada pada datasrc untuk gambarnya.

Marketplace Jd.id untuk scraping data produk berhasil pada nama produk dan foto produk, pada harga produk dan deskripsi produk tidak berhasil melakukan scraping dikarenakan pada markup tiap-tiap class ada yang sama dengan class pada deskripsi dan harga itu yang membuat tidak berhasilnya scraping Jd.id. Sedangkan pada e-markeplace Shopee dan Blibli tidak ada yang 
berhasil saat scraping nama produk, harga produk, deskripsi produk dan foto produk karena terdapat kendala yaitu keamanan pada script JS yang membuat scraping pada marketplace Blibli Shopee yang membuat tidak dapat scraping data produknya.

\section{E. Demografi Responden}

Berdasarkan hasil pengumpulan data melalui kuesioner yang disebar ke responden yang merupakan pengguna penjual online marketplace Tokopedia, Bukalapak, Lazada, Blanja, Zalora, Zilingo, Kriya, Alibaba, dan Amazon. Maka didapatkan 30 data, dengan rincian 7 data dari Tokopedia, 7 data dari Bukalapak, 2 data dari Lazada, 4 data dari Blanja, 3 data dari Zalora, 3 data dari Zilingo, 2 data dari Kriya, 1 data dari Alibaba, dan 1 data dari Amazon. Untuk lebih jelas dapat dilihat pada Tabel 2 berikut.

Table 2. Rincian Responden

\begin{tabular}{clcc}
\hline \multirow{2}{*}{ Responden } & \multicolumn{1}{c}{$\begin{array}{c}\text { Jenis } \\
\text { Marketplac }\end{array}$} & $\begin{array}{c}\text { Jumla } \\
\mathrm{h}\end{array}$ & $\%$ \\
\hline & Tokopedia & 7 & 23 \\
& Bukalapak & 7 & 23 \\
& Lazada & 2 & 7 \\
Bengguna (Penjual & Blanja & 4 & 14 \\
Online) & Zalora & 3 & 10 \\
& Zilingo & 3 & 10 \\
& Kriya & 2 & 7 \\
& Alibaba & 1 & 3 \\
& Amazon & 1 & 3 \\
& Total & 30 & 100 \\
\hline
\end{tabular}

Dari tabel diatas dapat dilihat bahwa sebanyak 23\% dari data pengguna merupakan penjual online Tokopedia, $23 \%$ penjual online Bukalapak, $7 \%$ penjual online Lazada, $14 \%$ penjual online Blanja, 10\% penjual online Zalora, $10 \%$ penjual online Zilingo, $7 \%$ penjual online Kriya, 3\% penjual online Alibaba, dan 3\% penjual online Amazon.

\section{F. Survei Responden}

Setelah melakukan Demografi responden, tahap selanjutnya yaitu survey responden dengan melakukan perhitungan total hasil dari skala likert pada masingmasing indikator performance expecrancy, effort expectancy, social influence, faciliting condition dan behavioral intention to use [10].

Performance expectancy mendapatkan total dari sangat tidak setuju 0 mendapatkan persentase $0 \%$, total tidak setuju 0 mendapatkan persentase $0 \%$, total netral 4 mendapatkan persentase $19 \%$, total setuju 37 mendapatkan persentase $15 \%$, dan total sangat setuju mendapatkan total sebanyak 79 dan persentase $28 \%$. Effort Expectancy mendapatkan total dari sangat tidak setuju 0 mendapatkan persentase $0 \%$, total tidak setuju 0 mendapatkan persentase $0 \%$, total netral 2 mendapatkan persentase $9 \%$, total setuju 63 mendapatkan persentase $26 \%$, dan total sangat setuju mendapatkan total sebanyak
52 dengan persentase $19 \%$.

Social Influence mendapatkan total dari sangat tidak setuju 0 mendapatkan persentase $0 \%$, total tidak setuju 0 mendapatkan persentase $0 \%$, total netral 5 mendapatkan persentase $24 \%$, total setuju 63 mendapatkan persentase $26 \%$, dan total sangat setuju mendapatkan total sebanyak 52 dengan persentase 18\%.Faciliting Condition mendapatkan total dari sangat tidak setuju 0 mendapatkan persentase $0 \%$, total tidak setuju 0 mendapatkan persentase $0 \%$, total netral 2 mendapatkan persentase $9 \%$, total setuju 54 mendapatkan persentase $23 \%$, dan total sangat setuju mendapatkan total sebanyak 64 dengan persentase $23 \%$.

Behavioral Intention to use mendapatkan total dari sangat tidak setuju 0 mendapatkan persentase $0 \%$, total tidak setuju 1 mendapatkan persentase $1 \%$, total netral 6 mendapatkan persentase $28 \%$, total setuju 43 mendapatkan persentase $18 \%$, dan total sangat setuju mendapatkan total sebanyak 40 dengan persentase $14 \%$. Untuk lebih jelas dapat dilihat pada tabel 3 berikut.

Table 3. Hasil Skala Likert Pada Kuesioner User Scraing.

\begin{tabular}{lllllll}
\hline No & Indikator & $\begin{array}{l}\text { Sangat } \\
\text { Tidak } \\
\text { setuju }\end{array}$ & $\begin{array}{l}\text { Tidak } \\
\text { Setuju }\end{array}$ & Netral & Setuju & $\begin{array}{l}\text { Sangat } \\
\text { Setuju }\end{array}$ \\
\hline 1 & & 0 & 0 & 0 & 8 & 22 \\
2 & Performace & 0 & 0 & 0 & 8 & 22 \\
3 & Expectancy & 0 & 0 & 3 & 12 & 15 \\
4 & & 0 & 0 & 1 & 9 & 20 \\
5 & & 0 & 0 & 1 & 14 & 15 \\
6 & Effort & 0 & 0 & 1 & 16 & 13 \\
7 & Expectancy & 0 & 0 & 0 & 17 & 13 \\
8 & & 0 & 0 & 3 & 16 & 11 \\
9 & & 0 & 0 & 0 & 16 & 14 \\
10 & Social & 0 & 0 & 2 & 14 & 14 \\
11 & Influence & 0 & 0 & 3 & 12 & 15 \\
12 & & 0 & 0 & 0 & 11 & 19 \\
13 & Facilitating & 0 & 0 & 0 & 17 & 13 \\
14 & Condition & 0 & 0 & 0 & 13 & 17 \\
15 & & 0 & 0 & 2 & 13 & 15 \\
16 & Behavioral & 0 & 0 & 2 & 15 & 13 \\
17 & Intention to & 0 & 0 & 3 & 14 & 13 \\
18 & Use & 0 & 1 & 1 & 14 & 14 \\
\hline
\end{tabular}

\section{KESIMPULAN}

Berdasarkan penelitian yang telah dilakukan dapat disimpulkan beberapa hal sebagai berikut.

1. Telah dibangun Sistem Informasi Web Scraping berbasis Web dengan menggunakan Framework Laravel 5.7.21 untuk mempermudah pelaku penjual online dalam mencari barang dan mengisi deskripsi produk dengan mudah dan cepat. Pelaku penjual online juga dapat mengelola produk pada emarketplace Tokopedia, Bukalapak, Lazada, Blanja.com, Zilingo, Zalora, Kriya, Amazon, dan Alibaba.

2. SI Web Scraping telah berhasil mengelola data user scraping, melakukan verifikasi terhadap pendaftaran user scraping terbaru, dapat melihat data pribadi user scraping, melihat lokasi user scraping yang 
telah berhasil bergabung, dapat melihat jumlah scraping yang telah terdaftar dan dapat melihat total gabungan scraping data produk Tokopedia, Bukalapak, Lazada, Blanja, Zalora, Zilingo, Kriya, Amazon, Alibaba pada setiap user scraping.

3. Setelah SI Web Scraping ini dibangun memiliki sebuah kendala yaitu pada Alibaba. Scraping data pada Alibaba Untuk deskripsi produk tidak dapat scraping gambar yang ada pada deskripsi produk Alibaba karena terjadi permasalan pada placeholder gambar Alibaba yang menjadi gambar utamanya.

4. Pada E-Marketplace Jd.id, Blibli, Shopee tidak dapat discraping data produknya karena terdapat markup class banyak yang sama dan keamanan pada script JS yang membuat scraping data produk tidak berhasil.

\section{DAFTAR PUSTAKA}

[1] Siska Maya. (2016). Strategi Peningkatan Penjualan Usaha Kecil Menegah Melalui E- Commerce Studi Kasus : Mitra Ukm Perusahaan X. Journal of Applied Business and Economics, 2, 271-279.

[2] Syuhada, A. A., \& Gambetta, W. (2013). Online Marketplace for Indonesian Micro Small and Medium Enterprises based on Social Media. Procedia Technology, 11(ICEEI), 446-454.

[3] Wijaya, R. C., Andjarwirawan, J., \& Palit, H. N. (2017). Aplikasi Pencarian Produk Jual Mobile Devices dari Berbagai Situs E-commerce. Journal of Information System, Vol. 4(1), 41-53.

[4] Rosario, M., Pratama, Y., \& Fachruddin. (2017). Penerapan Web Scraping Pada Websitecompany Profile. Dinamik-Jurnal Teknologi Informasi, 4(4), 37-43.

[5] Matthew Turland. (2010). Php | Architect's Guide to Web Scraping defined. Los Angeles.

[6] Josi, A., Abdillah, L. A., \& Suryayusra. (2014). Penerapan Teknik Web Scraping Pada Mesin Pencari Artikel Ilmiah. Jurnal Sistem Informasi (SISFO), Vol. 5(1), 159-164.

[7] Mitra, V., Sujaini, H., \& Negara, A. B. P. (2017). Rancang Bangun Aplikasi Web Scraping untuk Korpus Paralel Indonesia - Inggris dengan Metode HTML DOM. Jurnal Sistem Dan Teknologi Informasi (JUSTIN), Vol.5(1), 1-6.

[8] Sonya, I. P., \& Dr. Prihandoko, Sk. (2016). Analisis Web Scraping Untuk Data Bencana Alam Dengan Menggunakan Teknik Breadth-First. Jurnal Informatika Dan Komputer, Vol.21(3), 69-77.

[9] Roger S. Pressman. (2010). Software Engineering A Practitioners Approach Seventh Edition. New York: McGraw-Hill Companies, Inc.

[10] Venkatesh, V., Morris, M. G., Davis, G. B., \& Davis, F. D. (2003). User Acceptance Of Information
Technology: Toward A Unified View. MIS Quarterly, 27(3), 425-478. 